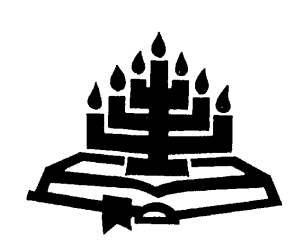

\title{
A qualitative investigation into the so-called ministry of deliverance
}

\author{
J. Janse van Rensburg \\ Faculty of Theology \\ University of the Free State \\ BLOEMFONTEIN \\ E-mail: jjvanr@yebo.co.za
}

\section{Abstract \\ A qualitative investigation into the so-called ministry of deliverance}

Since the publication of the book "The occult debate" (Janse van Rensburg, 1999) it has become clear that epistemological views on occultism within the reformed tradition have drastically diverged. During the General Synod of the Dutch Reformed Church in 2007, the report of the Algemene Taakspan vir Leer en Aktuele Sake (ATLAS) on a ministry of deliverance denied the existence of the devil and claimed that it would be unscientific to embark on an empirical research in this regard, because of the impossibility to verify information gathered in this manner. However, it is the hypothesis of this article that qualitative information could assist in attaining a clearer understanding of the need for a ministry of deliverance. In this article the methodology of the qualitative research is explained and the narratives of participants are revealed. Thereafter the responses of the participants are evaluated.

\section{Opsomming}

'n Kwalitatiewe ondersoek na die sogenaamde bediening van bevryding

Sedert die publikasie van die boek "The occult debate" (Janse van Rensburg, 1999) is dit duidelik dat daar uiteenlopende beskouings oor okkultisme in gereformeerde kringe bestaan. Gedurende die Algemene Sinode van die NG Kerk in 2007 het die verslag van die Algemene Taakspan vir Leer en Aktuele Sake (ATLAS) beweer dat die duiwel as persoon nie bestaan nie en dat daar geen ruimte vir 'n bediening van bevryding is nie. Daar is verder beweer dat enige kwalitatiewe navorsing hieroor onbetroubaar en dus onwetenskaplik sou wees. Dit is 
egter die hipotese van hierdie artikel dat kwalitatiewe navorsing 'n betekenisvolle bydrae kan lewer om meer lig op 'n bediening van bevryding te werp. In hierdie artikel word die metode van kwalitatiewe navorsing wat gebruik word, beskryf en die narratiewe van deelnemers word aan die orde gestel. Laastens word die response van deelnemers geëvalueer.

\section{Statement of the problem}

Although Theron (2001:180) was of the opinion that up to 2001 there was a marked increase in global research on occultism and a ministry of deliverance, very little has recently been published in scientific articles to further the discourse. Klutz (2004:2-3) refers to the lack of interest in research on the exorcism narratives among New Testament scholars.

One of the most prolific reasons may be that biblical references to angels, demons and demon possession have lately been branded as residues of a premodern worldview (cf. the brief discussion by Viljoen \& Floor, 2006; Viljoen, 2006) which can no longer be accepted, given our modern scientific knowledge (DRC, 2007:18-30). Likewise, Klutz (2004:13) highlights the fact that most scholars of the New Testament "probably have little or no room for such beliefs within their own Weltanschauung". However, after studying three narratives of exorcism, Viljoen (2006:773-785) concludes that demon possession was a stark reality according to the Gospels, but Jesus demonstrated his absolute authority over Satan and his demons in a unique way.

The view that demons simply do not exist (Kirkpatrick, 2007:19) implies that any ministry of deliverance and other forms of demonic influences are perceived to be nonsensical. The DRC (2007:27) goes further to suggest that ministers who involve themselves with a ministry of deliverance might reflect some kind of personality disorder.

While Vergeer (2002:372) shows how a variety of synods of the Dutch Reformed Church responded negatively toward a ministry of deliverance, Theron (2006:196) is of the opinion that such resistance is beginning to disappear. He refers to "some decisions of the different Dutch Reformed Church Synods [that] seemed to be more open to the possibility that this ministry holds".

Undoubtedly we have here different perceptions about the dispensation in reformed circles. Analyses of reports before different general synods of the Dutch Reformed Church rather seem to support 
the findings of Vergeer. They indicate a move in the opposite direction away from acknowledgement. In 1986 the particular report on a ministry of deliverance (DRC, 1987:143-146) acknowledged the real existence of the devil, while Christians are warned that dabbling in the occult may have serious consequences. The Dutch Reformed Church even goes further to suggest that more attention should be given to the subject of occultism in the training of ministers at theological faculties.

Yet, in 2007 the compilers of the report suggested that the reality of a personal devil should be denied. The Dutch Reformed Church consequently rejected a ministry of deliverance, clearly moving away from the thinking of 1986 (DRC, 1987:143-146). The report of 2007 (DRC, 2007:18-30) was not accepted by the synod and the research was referred back to the committee.

Clearly the diversity in opinion and paradigm which Janse van Rensburg (1999:3-19) referred to, still exist. In response to an article in Kerkbode, the official newspaper of the DRC (Janse van Rensburg, 2005), rev. André O'Kennedy enters via e-mail into a serious debate about such epistemological differences. This seems to be another detrimental factor in advancing the research.

Of course, epistemological differences precipitate an arrangement and interpretation of facts in such a way as to substantiate a certain view. For example, the DRC takes as point of departure that perceptions on occultism is fed by a need (italics - JJVR) for the existence of a spiritual world (DRC, 2007:19). It is then argued that occultism feeds this need. This implies that the need for a spiritual world creates the world of the occult. However, people who have done research on the field of occultism and people who are involved with a ministry of deliverance would simply not accept such an assumption (cf. De Beer \& Van den Berg, 2007:24-30; Ouweneel, 1978).

Other factors also play an important role in mudding the waters of the discussion. We will seriously have to consider the opinion expressed by Theron (2003:194-212; 2006:198-201) that terminology such as possession and exorcism used in the past, proved not to be helpful in furthering the research. While he is hesitant to derive at terminology if such words are not found in the original text, Vergeer (2002:378-381) supplies a list of relevant concepts which could be linked to Greek words indicating demonic influence of some kind.

Even the term deliverance causes irritation among some sceptics, because it seems to support the phenomena of "possession" and 
"binding". Of course, this need not be a stumbling block. The term liberation used by Clinebell (1987) in his holistic approach might be an alternative as it has the same root meaning, but without the unnecessary baggage of "possession" or "binding". This means that a ministry of deliverance (liberation) could be acknowledged even by those who do not subscribe to the possibility of possession or binding. After all, it is clear that such a ministry amounts to much more than deliverance from binding or possession (De Beer \& Van den Berg, 2007).

All these factors raise the question whether any new approach to research on the occult debate could eliminate such epistemological differences and further the discourse. It is quite significant that the DRC (2007:19-20) outright rejected any possibility of empirical research on occultism.

This approach is not substantiated by research in the field of Social Sciences and Practical Theology (Brunsdon, 2006:192).

\section{Hypotheses}

It is precisely at this point that this article enters into the debate. Theron (2006:191-204) stresses the need for incorporating the stories and experiences in the development of practical theological theories. It is, therefore, the hypothesis of this article that qualitative research can indeed make a major contribution to furthering the discourse. Extensive attention is given to the method of qualitative research precisely because the DRC (2007), as previously mentioned, found this to be an unscientific method of gathering information.

\section{Methodology}

Being a qualitative project, this article has taken basis theoretical points in the discourse under discussion as vantage point. The narratives of a selection of people currently involved with a ministry of deliverance will be presented. Participants were allowed to express these personal perspectives and even elaborate where they found it necessary. The difference between this qualitative approach and quantitative research is apparent. Near the end of the process the semi-final manuscript of the research article was made available to all participants for comments and further feedback. All participants gave permission to reveal their true identity. 


\section{Goals of the research}

It is not the purpose of this article to become involved in an elaborate basis theoretical discourse on occultism per se. It would also be impossible, taking the research problem into consideration, to elaborate on practices of deliverance in many other religions. However, the fact that they do exist, seems to strengthen the hypothesis that there is a common need for such a ministry. It would also be wrong to conclude that only success stories were chosen, since the method of qualitative research differs from quantitative research. The focus is not on success and the fact that such a ministry works, but rather on the need for such a ministry and the integrity with which it is approached by participants.

\section{The nature of qualitative research}

The qualitative research was guided by the following academic guidelines:

- Qualitative research deals with people's emotions, experiences and perceptions. It is a hermeneutic approach, which seeks to understand the participants in their context in an inter-subjective interaction (Van Zyl, 2006). Hermeneutics may be explained as understanding through interpretation (Pieterse, 1993:72).

- This method deals with words, not statistics. It wants to establish the meaning and emotions behind words and tries to interpret them (Mouton, 1993:53-75). It endeavours to identify and evaluate the religious motives for social and religious behaviour (Pieterse, 1993:186; Kvale, 1992:51).

- According to Mouton (1988:1-16) qualitative research could be done through different methods like personal documents, letters, diaries and biographies. Even photos, tapes and videos could also be the source of qualitative research, according to Mouton. In all these examples personal contact is not an indispensable requirement. Within this framework it was decided to communicate with participators by e-mail if they are not available for personal conversations.

- It is well noted by the researcher that according to Mouton and Marais $(1989: 157 ; 1988)$ qualitative research in a hermeneutic approach favours unstructured conversations. However, the choice of paradigm will undoubtedly influence the process of the research. A postmodern epistemology might lead to a postfoundationalist approach (Müller, 2005:72-88; Alvesson, 2002:17-18). 
Such research would be spontaneous, unplanned and value free. Freedman and Combs (2002:17-18) explains: "We think about information as being generated rather than 'gathered' in therapeutic conversations ...". Within a postmodern epistemology an element of teaching and training towards change is in principle not the aim. Therapy does not endeavour to change people, says Maturana (1985:43) and Tomm and Lannaman (1988:37).

Personally, I am inclined to agree with Bothma (2003:201) in working with micro maps. There are predetermined guidelines for the direction of the process and themes for discussion (cf. also Mouton, 1988). This will ensure that the process does not end in no man's land, thereby rendering the results of the research to be meaningless (Mason, 2002:227). Babbie (1998:139) makes a distinction between the conceptualisation (planning) and the operationalisation (execution) of the research. It goes far beyond mere questionnaires that are easily drawn up and distributed. As such it is a very structured methodology (Babbie, 1998:141-145) where relevant issues in the discourse, as indicated in the statement of the problem, will be addressed (Becker, 1970) and interpreted (Mason, 2002:225-241).

- It is a client centred approach inasmuch as the client's thoughts, actions and emotions are dominant. However, this does not mean that the researcher is uninvolved. When Anderson and Goolishian (1992:26) speak of the researcher's position of not knowing and the client being the expert, thereby creating a "hermeneutic and interpretative position" regarding therapy, it does not neutralise the knowledge and values that the researcher brings into the process (cf. Hoffman, 2002; Janse van Rensburg, 2000: 18-21) and allows the researcher to lead "from one step behind" (Cantwell \& Holmes, 1995:37). Therefore, it is not the intention of the researcher to enter into debate with the participants about their perspectives and practices, but rather to deconstruct and coconstruct with the participants in an inter-subjective fashion (Marshall, 1999:79-86), thus becoming an insider researcher (Dreyer, 1998:17).

- From the above it is clear that qualitative research is predominantly descriptive. As such it has no intention of formulating principles to be generalised or to derive at conclusions that are to be made applicable to all. For this reason Bothma (2003:iii) correctly warns in the foreword to his dissertation that it is not the intention to prove anything, but rather to facilitate an opportunity for the participants to tell their story. 
- For reasons explained above (cf. also Leedy, 1997), it is possible to work with only one case study, as Bothma (2003) and Brunsdon (2006) did, yet still present a valid research project. Participants are chosen in accordance with the research problem, hypotheses and goals of the research. In this current research the participants were selected because of their integrity in personality and faith as well as their experience with a ministry of deliverance.

- The question of validity in qualitative research is a much discussed subject. The researcher must show transparency in his methodology, explaining why and how the participants were selected, as well as the choice of method for the gathering of information and the method of documentation (Bryman, 1994). However, other considerations might influence the validity of qualitative research, for example the stature of the researcher (Steyn \& Lotter, 2006:115). If it is not possible to verify facts, how is it possible to establish what really happened? This was the objection of the DRC (2007) regarding the inclusion of phenomenology in research on a ministry of deliverance. According to Steyn and Lotter (2006:108) the search for validity in qualitative research is a remnant of modernity. Furthermore, the researcher enters the process with some knowledge, professionalism and the ability to observe and evaluate people's responses (Becker, 1970:75-77). If all possible precautions have been taken, the results of the process then reflect the responses of participants as it was noted. One can do only so much. It is also to be remembered that the same risk of validation exists with quantitative research. How will the researcher(s) know whether the answers given in a questionnaire are true or false? In the final analysis one must remember that the purpose of qualitative research is not to validate information on a broad level, but merely to describe the responses of particular people within a certain context. The problem of validations and subjectivity should, therefore, be seen in context.

- Rory O'Brien (1998) describes action research as "learning by doing". He explains: "A group of people identify a problem, do something to resolve it, see how successful their efforts were, and if not satisfied, try again." Participatory action research, therefore, endeavours to supply the social sciences with information so that something could be learnt from the effort. This involves an intersubjective process of deconstruction and reconstruction, indeed, a process of reframing in order to facilitate a second order change (Capps, 1990:12-13), resulting in a change 
of the status quo. From the above it is clear that narrative therapy fits participatory action research like a hand in a glove (Lawler, 2002:242), although this does not mean that only narrative therapy has this ability.

\section{Narratives}

On this aspect we are only interested in that part of the history that has any kind of relevance to the participant's view on the matter of deliverance and then as brief as possible. Names used are authentic in all cases with the consent of participants. Only Helene and her husband and Roux have some kind of Christian relationship with one another, but all participants operate with an own ministry and is in no way influenced by the views, experiences or practices of each other. Interviews were conducted during the period of August to September 2008.

\subsection{Mariette Schlebusch}

Mariette Schlebusch had quite a dramatic story to tell. She got involved in occultism from the early age of nine years. At the age of ten she was able to levitate a mature man. She became intrigued by the powers she could acquire by dabbling in the occult. She believed it to be her powers, only to realise later on that it was the powers of Satan working through her. She testifies to the role of the Bible in her own deliverance. When she committed her life to Jesus Christ, it was the words of Ephesians 1:17-23 that played a major role, emphasising the importance of a living relationship with Christ. Since her deliverance she has become actively involved with a group called Auksano, where she had the opportunity to use her knowledge of God's Word (which has grown impressively) and her own deliverance to help young people involved in occult practices and drug abuse.

\subsection{Roux Meyer}

Roux Meyer was not involved in any form of occultism. His first encounter with the occult came while he was a youth leader. At a youth gathering one of the young boys (who was befriended with an active Satanist) went into a trance from which they could not deliver him. They took the boy to the minister, who refused to be involved. This prompted them to make contact with ministers who had some knowledge about deliverance. Gradually they realised that the 
authority of the Name of Jesus Christ over evil powers was all important. ${ }^{1}$ Meyer reports that since then, he was involved with a ministry of deliverance from time to time, as it came upon his way. Of great significance is his closing remark that he has received university training in Bible knowledge and was taught to test everything according to Scripture. He continues: "I am therefore not a person who allows my emotions to run away with me. However, you can't argue with what you experience in real life."

\subsection{Helene Theron}

Helene Theron and her husband have been involved with a ministry of deliverance for sixteen years. She had a similar experience with a young boy who went into a trance during a christian youth meeting. As they could not find a minister who was willing or able to help, they took him to a farm where he was cared for. The next morning he was out of the trance and they told him about the love of Jesus Christ. He was previously involved in Satanism, but when he accepted Christ as saviour he was completely healed. Because of their involvement with the youth, more such incidents occurred. One girl remained in what seemed to be a catatonic position and was quite unmoved. Theron and others who were with her, simply prayed for the girl, commanding any possible demons to leave. Theron testifies that this girl was so completely delivered that the change in her was almost unbelievable. Since these incidents she and her husband are invited to speak at church meetings, school meetings and seminars. They present an average of three seminars per month and she mentions the names of ministers and congregations as references for the work that they do. This seems to authenticate their ministry of deliverance.

\subsection{André O'Kennedy}

André O'Kennedy is a minister in the Dutch Reformed Church with an apparent extensive knowledge and experience of a ministry of deliverance. Since personal conversations were not possible, he responded by e-mail, submitting almost a mini dissertation with his comments on the questionnaire, combining his own experiences with literature references on occultism and deliverance. Because of the elaborate nature of his response it is impossible to report all his

1 This conviction is mentioned by more than one participant. 
approaches, experiences and convictions. However, an effort will be made to reflect the core of his ministry. ${ }^{2}$

\section{The role of Scripture}

The first department of the questionnaire, dealing with participant's view of the Bible, was considered to be necessary and important in order to establish a relationship between what the Bible communicates about the matter and whether participants interpret these facts literally or not. All participants witnessed to the importance of Scripture - not only in their own relationship with God in Christ, but also to the importance of information which forms the point of departure for their ministry. All participants accept the reality of the existence of demons and the occult powers which can influence people in one way or another. Comparisons are made between what the Bible says and what participants have seen and experienced in their ministry. According to O'Kennedy, what he has seen and experienced helps him to better understand the narratives of Scripture.

For Meyer a true understanding of Scripture is necessary through scientific exposition. Both he and O'Kennedy deem the historical context of passages of Scripture to be important. This reflects a responsible use of the Bible in trying to understand its message on deliverance. In this regard O'Kennedy's hermeneutic approach to understanding Scripture is noteworthy. O'Kennedy writes:

Although the occult is not the scope of the gospel, God and Christ's confrontation with and triumph over Evil is a central theme in the New Testament. I am convinced that we cannot fully comprehend the implications of the Kingdom of God if we do not take this into account.

Regarding the assumption of an old worldview, O'Kennedy investigates this assumption objectively and considers two possibilities. Either Jesus merely respected people's ideas about demons and illness and pretended to cast out demons, or Jesus simply healed people and the authors of the synoptic Gospels and the spectators interpreted these miracles as the casting out of demons. However, both these hermeneutic possibilities are unacceptable to him. O'Kennedy testifies to the fact that previously he also used the argument that those illnesses could today be explained and described by

2 After reviewing the articles André reported that he was quite satisfied with the way he was reported and had nothing to add. 
medical science. In ancient times, such illnesses were not known and could therefore easily be interpreted as demonic manifestations. However, his experience with a ministry of deliverance convinced him otherwise. In this regard he refers to the respected psychiatrist Scott Peck who was involved with two incidents of deliverance and who wrote two books on these cases, explaining his conviction that these were genuine cases of possession. Peck writes that, although he could not prove the existence of demons, his experience with these two cases convinced him of the reality of their existence. On the question whether demons really exist, O'Kennedy's remark corresponds with that of Peck: "I have never had any person, sceptic or curious, who would have any doubts about the real existence of demons after attending a session of deliverance." (Translation JJvR.)

\section{Demons and posession}

Section B of the questionnaire deals with questions about the perceptions and experiences of participants concerning the real existence of demons. These questions were stimulated by the assumption of the DRC that demons and Satan do not exist.

All participants were convinced and adamant that demons really exist. Schlebusch explains that, while she had the ability to see into the spiritual world (an ability that she possessed from an early age), she literally saw demons and angels. She (like many others) is able to describe or draw what she saw. She rejects the possibility that these "sightings" were precipitated either by some psychological state or by the abuse of drugs.

The link between what the Bible describes and what he experienced in his ministry is confirmation for Meyer that demons do really exist. He narrates incidences where people went into a trance in response to the mention of or praise to the Name of Jesus Christ. Multivocal speaking (different voices coming from within the one person) ${ }^{3}$ affirms the presence of demons, according to his experience. O'Kennedy explains this phenomenon by saying that it seems as though demons are merely using the vocal cords of the client. He narrates an occasion where he ministered in Mozambique and

3 I have elsewhere indicated this phenomenon to be one of the few authentic indications of demon possession (Janse van Rensburg,1999:49). This seems to be authentic, because it is a phenomenon described by many while it also cannot be imitated. 
addressed a demon in Afrikaans. Not only did the demon respond, but a voice speaking in Afrikaans came from the person who did not know Afrikaans, proving that it was not the person speaking.

Unusual violent responses seem to be a common denominator experienced by all participants. From her own experience while she was involved with occultism Schlebusch reports that she would suddenly and without explanation become so violent that she would break her own guitar or attack her mother and sister. Afterwards, she would not be able to remember what she did. Of course such blind aggression is not unfamiliar in psychology, but given the history of occult involvement the possibility of occult influence should at least be considered.

Are these not merely violent responses precipitated by psychological conditions? As with Schlebusch, Meyer argues that if these manifestations were precipitated by a psychological condition, clients would not react in such a violent manner by the mention of the Name of Jesus Christ. Significant, says Meyer, is the incredible peace experienced after demons were reprimanded in the Name of Christ. O'Kennedy is very clear on the matter of demonic influence versus psychopathology. According to him there are three main reasons why demonic manifestations could not be explained as psychological conditions. Firstly, with demonic influence the use of medication, which would normally be effective in psychological conditions, would not have the required effect. Secondly, the vehemently negative response towards prayer and the Name of Jesus Christ, so typical of demonic activity, is not present with psychopathology. Thirdly, symptoms for occult manifestations and behaviour are too precise to be confused with psychopathology.

Of great value for consideration is O'Kennedy's comparison between psychopathology and occultism. He discusses different pathologies like clinical depression, bipolar disturbances, Tourette's syndrome, et cetera, and offers viable options to distinguish between occult influences and such pathology. These discussions show that it is an over-simplified strategy to merely associate biblical stories of demon possession with epilepsy.

\section{A ministry of deliverence}

An interesting point is made by O'Kennedy (also mentioned by Schlebusch) that it is not so strange in a postmodern age to give attention to the realm of the spiritual world and people dabbling in the occult, since the New Age movement encourages people to 
discover their psychic abilities. Interest in spiritism, witchcraft and clairvoyance has drastically grown among all layers of society.

Noteworthy is the repeated experience of many involved with such a ministry, that members of churches would prefer their minister to give pastoral assistance, but that in more than one case the particular minister who was approached, was either not willing or not able to help. This is indeed enough reason for further investigation. It would be very interesting to determine with an empirical research why ministers (particularly of the Dutch Reformed Church) did not want to assist people troubled by occult experiences. Was it because they do not believe in such phenomena? Were they afraid, or was it merely because they lacked the knowledge and know-how that was needed to help people in need?

O'Kennedy's description of his ministry reflects an interesting diversity, explaining that his ministry of deliverance does not always incorporate direct occult manifestations or behaviour. He admits that there are influences that could cause manifestations other than by occult influence. Among these are psychological conditions causing people to try to imitate possession and wanting deliverance, drug abuse, suggestion and hypnosis. These factors are also confirmed by Schlebusch. Although Meyer is convinced that authentic occult behaviour can't be imitated, he admits to the possibility of the influence of drugs in manifestations. O'Kennedy sides with a psychologist called Lechler in stating that, although pseudo demonising seems to be a general occurrence, it could easily be distinguished from real possession and/or manifestations.

Often people need deliverance from trauma or spiritual pain, which may be subtle reasons for people's openness to demonic influences like bitterness and hatred. Schlebusch reported that the abuse that she experienced from her father was the main reason for her need for revenge, turning away from the God of her father (a religious person) to Satan and occultism. Similarly, O'Kennedy narrates the tragic story of a little girl who was sexually abused and raped by close family. These events made her turn to Satanism. Once children are forced to participate in satanic rituals, they are so traumatised by those events that they desperately need deliverance from such terrible memories and feelings of guilt.

The diversity of O'Kennedy's ministry includes deliverance from demonic influences regarding trauma, curses, inheritance of occult powers, abilities or attractions, persistence in sin, a variation of occult activities and illness, both psychological and physical. All these 
phenomena are explained in O'Kennedy's response, accompanied by elaborate motivation and examples of his ministry in each category.

The first question on Section $C$ addresses the problem of terminology. There is a general agreement that familiar terms in the discourse on a ministry of deliverance, like possession, deliverance, exorcism, et cetera, are loaded with a diversity of meanings and carry a baggage of associations that clouds the discussion. O'Kennedy's analysis in this regard is quite elaborate and culminates in the suggestion that new terms should be developed in the ongoing discourse. This is in agreement with the findings of Theron (2003: 194-212; 2006:198-201).

O'Kennedy emphasises that he is uncomfortable with the perception of a method or model for deliverance. His ministry of deliverance is very similar to any other pastoral discussion, where the use of a narrative approach plays a major role. He feels strongly about a teams-approach which could mean an interdisciplinary professional partnership or it could refer to a team of Christians having different gifts, thereby serving the joint purpose of deliverance with the variety of gifts.

Should all ministers have such a ministry of deliverance or is it a specialty field? Meyer feels that this ministry is in fact a speciality field, because of the different gifts that Christians receive. He also reiterates that all Christians should have a basic knowledge in this field. Schlebusch agrees that all Christians are filled with the Holy Spirit and should therefore have a basic knowledge. Yet, she is convinced that it is a field of special ministry for which training is indispensable, although this training does not imply basic rules, fixed structures or predetermined steps of deliverance. O'Kennedy also sides with a ministry of deliverance as a speciality field, although his view is that all ministers should acquire the competence to serve the Lord in this way. Those who choose not to be involved should not stand in the way of those who are convinced that they have received the call to such a ministry.

One last question remains. Is it possible for Christians to be possessed by demons? This is probably the one issue that causes the most disagreement. O'Kennedy's experience from his ministry of deliverance is that it is possible. He reports that it was an initial shock to him to discover that many Christians do have some form of demonic influence or possession. The overwhelming majority of his clients are Christians of whose faith there is no reason for doubt. 
This experience is shared by Dickason (1987:127) who reports working with more than 400 Christians. O'Kennedy also refers to Koch, Verduijn, Kraft and Anderson who all agree that the theological theory that Christians could not be possessed or influenced is proven wrong in the practice of a ministry of deliverance. Meyer seems to prefer the term binding for situations where Christians are plagued by occult phenomena. He has often found this to be the case, but prefers not to call it possession. Regarding the issue of terminology Schlebusch comments that we could so easily get involved in arguments about terminology while the work God wanted us to do, is left asunder.

\section{Discussion}

It is of the greatest importance to be reminded of the nature and goals of qualitative research. In this regard the intention of the researcher is not to make general conclusions which are to be considered as proof of a certain point of view in the discourse on a ministry of deliverance. What is presented here are the stories, convictions, emotions and surveillances of participants. However, in as far as their stories correspond in many ways, we may certainly deduce that if participants independent of each other experience the same manifestations and responses, the phenomenon could certainly not be ignored or written off. 4 In fact, their experiences also correspond with information in authoritative literature like that of Ouweneel (1978), Koch (1972) and Huisamen (1990). Is the value of qualitative research not precisely to take note of people's narratives as an added source of information on a certain theme of research?

It seems clear that all participants base their ministry of deliverance on a literal interpretation of passages of Scripture concerning demon possession and deliverance. This strongly indicates that the view on the nature and character of Scripture is of the utmost importance in the debate. The DRC worked with an epistemology that explains the narratives in Scripture as part of an old worldview. However, many experiences in the entire participant's ministry have convinced them that the Bible stories are real. Again it is apparent that ways within theology and church depart when views on Scripture do not concur.

4 Schlebusch points out that more and more people (ministers, elders, teachers, young people and leaders) are seeking help from individuals and organisations involved with a ministry of deliverance. 
In my research I was prolifically aware of the integrity of the participants, not only in terms of the truthfulness of their narratives, but also and especially of the integrity of their personality. In this regard it is shocking to again read the insinuation in the report that people with a ministry of deliverance could themselves have some kind of underlying psychopathology (DRC, 2007:27). I have not found any reason to doubt the soundness of mind and spirit in any of the responses of any of the participants. Furthermore, the fact that most of them are invited to speak at schools and help in certain cases, sometimes even invited for return visits, strongly indicate that others (such as school principals, teachers and ministers of congregations) have found them to be people of integrity.

The narratives of the participants succeeded in illustrating how necessary and important a ministry of deliverance really is. The very term deliverance is objectionable for some who do not accept the existence of Satan and demons. However, even if the real existence of demons is taken out of the equation, deliverance is still needed and applicable. In this regard we may, as an alternative, speak of a ministry of liberation (Clinebell, 1987). If deliverance is not to refer to deliverance from demonic influence, then there is clearly still a great and urgent need for deliverance from involvement with satanic rituals, drug and sex addiction, intimidation so typical of subcultures, guilt feelings about involvement with occult rituals and personality deficiencies which may underlie and motivate clients to dabble in the occult. Noteworthy in this regard is that Auksano (an organisation helping people who are involved with occultism) reports in their newsletter of July/August 2008 that 230 therapy sessions were handled in connection with drug abuse, occultism and trauma during May and June, while about 250 telephonic therapy sessions were also conducted. This clearly proves the urgent need for help among those who are involved with occultism. Furthermore, it is clear from the stories of the participants of this research that clients who have been delivered experienced the freedom of which Christ said: "If the Son has set you free, you will truly be free." (John 8:36.)

\section{Conclusion}

Qualitative research intends to take the narratives of people seriously. These are the stories of only a few people who try to serve God through their ministry. How could we simply disregard their stories and many others? Do we not have a responsibility to the members of churches and even non-believers who come to the church for help? If we refuse to help, they might seek refuge with 
people and practices that could really be damaging or leave them in the despair and fear of their hopeless situation. Even if we take the worldview argument seriously, it does not exclude the need to also take a ministry of liberation seriously, says Theron (2006:191-206). Somewhere between these two extremes we may find some indications of a new and more comprehensive understanding of this dialectical dilemma which we face.

\section{List of references}

ALVESSON, M. 2002. Postmodernism and social research. Philadelphia: Open University Press.

ANDERSON, H. \& GOOLISHIAN, H. 1992. The client is the expert: a notknowing approach to therapy. (In McNamee, S. \& Gergen, K.J., eds. Therapy as social construction. London: Sage. p. 25-39.)

AUKSANO. 2008. News letter. July/August.

BABBIE, E. 1998. The practice of social research. Albany: Wadsworth.

BECKER, H.S. 1970. Sociological work: method and substance. Chicago: Aldine.

BOTHMA, J.D. 2003. Pastorale terapie met die MIV/VIGS geaffekteerde familie: 'n narratiewe benadering. Bloemfontein: Universiteit van die Vrystaat. (Ongepubliseerde doktorale proefskrif.)

BRUNSDON, A.R. 2006. Pastoraat aan die afgetrede egpaar deur kanker geaffekteer: 'n narratiewe benadering. Bloemfontein: Universiteit van die Vrystaat. (Ongepubliseerde doktorale proefskrif.)

BRYMAN, A. 1994. The Mead/Freeman controversy: some implications of qualitative research. (In Burgers, R.G., ed. Studies in qualitative methodology. Vol. 4. Aldershot: Awebury. p. 1-70.)

CANTWELL, P. \& HOLMES, S. 1995. Cumulative process: a collaborative approach to systematic supervision. Journal of systematic therapies, 14(2):35-46.

CAPPS, D. 1990. Reframing - a new method in care. Minneapolis: Fortress.

CLINEBELL, H. 1987. Basic types of pastoral care and counselling. Nashville: Abingdon.

DE BEER, M.J. \& VAN DEN BERG, J.-A. 2007. Die ondersteuning van okkultgerehabiliteerdes: 'n pastoral-teologiese model vir die toerusting van fasiliteerders. Acta theologica, 27(2):23-43.

DICKASON, C.F. 1987. Demon possession and the Christian. Wheaton: DRC Crossway.

see DUTCH REFORMED CHURCH

DREYER, J.S. 1998. The researcher and the researched: methodological challenges for practical theology. Praktiese teologie in Suid-Afrika, 13(1):14-27.

DUTCH REFORMED CHURCH. 1986. Report of a Comity to the General Synod. Agenda, 143-146.

DUTCH REFORMED CHURCH. 2007. Report of a Comity to the General Synod. Agenda, 18-30. 
FREEDMAN, J. \& COMBS, G. 2002. Narrative therapy with couples ... and a whole lot more! A collection of papers essays and exercises. Adelaide: Dulwich Centre.

HOFFMAN, L. 2002. 'n Verbondgefundeerde paradigma vir die pastorale begeleiding van die egpaar met fertiliteitsuitdagings. Bloemfontein: Universiteit van die Vrystaat. (Ongepubliseerde doktorale proefskrif.)

HUISAMEN, E. 1990. Magte van die duisternis. Kaapstad: Lux Verbi.BM.

JANSE VAN RENSBURG, J. 1999. The occult debate. Cape Town: Lux Verbi.BM.

JANSE VAN RENSBURG, J. 2000. The subject of pastoral care: an epistemological discourse. Kaleidoskoop 2000. Acta theologica, (Supplementum 1): p. 1-25.

JANSE VAN RENSBURG, J. 2005. Demone kry te maklik skuld. Kerkbode: 23 Sept.

KIRKPATRICK, J. 2007. Bestaan die duiwel? Teo.co.za.nuusbrief.2007:19.

KLUTZ, T. 2004. The exorcism stories in Luke-Acts: a sociostylistic reading. Cambridge: Cambridge University Press.

$\mathrm{KOCH}, \mathrm{K}$. 1972. Between Christ and Satan. Michigan: Baker.

KVALE, S. 1992. Postmodern psychology: a contradiction in terms. (In Kvale, S., ed. Psychology and postmodernism. London: Sage. p. 31-57.)

LAWLER, S. 2002. Narrative in social research. (In May, T. Qualitative research in action. London: Sage. p. 242-258.)

LEEDY, P.D. 1997. Practical research: planning and design. 6th ed. Upper Saddle River: Prentice Hall.

MARSHALL, C. 1999. Designing qualitative research. London: Sage.

MASON, J. 2002. Qualitative interviewing. (In May, T. Qualitative research in action. London: Sage.)

MATURANA, H. 1985. An interview with Humber - to Maturana. Networker, 3643, May/Jun.

MOUTON, J. 1988. The philosophy of qualitative research. (In Ferreira, M. \& Mouton, J. Introduction to qualitative research. Module 3. Pretoria: HSRC. p. 1-16.)

MOUTON, J. 1993. Thomas S. Kuhn. (In Snyman, J., ed. Conceptions of social inquiry. Pretoria: HSRC. p. 53-75.)

MOUTON, J. \& MARAIS, H.C. 1988. Basic concepts in the methodology of the social sciences. Pretoria: HSRC.

MOUTON, J. \& MARAIS, H.C. 1989. Metodologie van die geesteswetenskappe: basiese begrippe. Pretoria: Insto-Print.

MÜLLER, J.C. 2005. A postfoundationalist, HIV-positive practical theology. Praktiese teologie in Suid-Afrika, 20(2):72-88.

O'BRIEN, R. 1998. An overview of the methodological approach of action research. Toronto: University of Toronto Press.

OUWENEEL, W. 1978. Het domein van de slang. Amsterdam: Buiten \& Schipperheijn.

PIETERSE, H.J.C. 1993. Praktiese teologie as kommunikatiewe handelingsteorie. Pretoria: RGN.

STEYN, R.S. \& LOTTER, G.A. 2006. Voorhuwelikse verhoudings: 'n verkennende kwalitatiewe empiriese ondersoek. Praktiese teologie in Suid-Afrika, 21(1):104-120. 
THERON, J.P.J. 2001. Die ontwikkeling van 'n groeiende bevrydingsbediening: 'n literatuuroorsig veral met verwysing na invloedryke persone en kerklike tradisies. Acta theologica, 21(1):180-197.

THERON, J.P.J. 2003. "Beset", "besete" of "beserk"? Besinning oor enkele begrippe binne die kerklike diens van bevryding van bose magte. Acta theologica, 23(1):194-212.

THERON, J.P.J. 2006. The ministry of deliverance from evil forces: the need for academic reflection in pentecostal churches in Africa. Praktiese teologie in Suid-Afrika, 21(3):191-206.

TOMM, K. \& LANNAMAN, J.W. 1988. Constructivism applied: the constructivist challenge. Networker, 37-38, Sept./Oct.

VAN ZYL, A.P. 2006. Pastorale terapie met betrekking tot die moeder met postpartum depressie. Boemfontein: Universiteit van die Vrystaat. (Ongepubliseerde doktorale proefskrif.)

VERGEER, W.C. 2002. Okkultiese binding en bevryding: 'n Nuwe-Testamentiese perspektief. In die Skriflig, 36(3):369-395.

VILJOEN, F.P. 2006. Jesus se genesing van besetenes in die lig van drie voorbeelde uit die Evangelies. Nederduitse Gereformeerde teologiese tydskrif, 47(3 \& 4):773-785.

VILJOEN, F.P. \& FLOOR, L. 2006. Goeie en slegte engele: 'n perspektief uit die Bybel. In die Skriflig, 40(1):35-56.

\section{Key concepts:}

deliverance, ministry of

occultism

participatory action research

pastoral care

terminology

\section{Kernbegrippe:}

bevryding, bediening van

deelnemende aksienavorsing

okkultisme

pastorale sorg

terminologie 
